\title{
Peadiatric wheat challenge study-preliminary results
}

\author{
Nora Nilsson ${ }^{1 *}$, Gunilla Hedlin², Caroline Nilsson ${ }^{3}$, Magnus Borres $^{4}$ \\ From Food Allergy and Anaphylaxis Meeting 2011 \\ Venice, Italy. 17-19 February 2011
}

\section{Background}

In addition to cow's milk, egg, soy, peanut, tree nuts and fish, wheat is also a food causing allergy in children. Wheat allergy is more prevalent in the northern part of Europe. Methods commonly used today in clinical practice to diagnose wheat allergy have a limited value in predicting a clinically significant wheat allergy compared with the test results for egg, milk and peanuts.

\section{Aim}

To investigate what proportion of children with a diagnose of wheat allergy exhibit clinical symptoms upon oral food challenge with wheat and to identify if some children unnecessary avoid wheat.

\section{Material and Methods}

27 children from Stockholm sensitized to wheat and subject to an elimination diet were tested for IgE antibodies to: wheat and $\omega-5$ gliadin. All 27 patients were positive to IgE antibodies to wheat and underwent food challenge test. The initial oral food challenge test consists of $0,05 \mathrm{gr}$ of bread which is followed by six steps with increasing dose. The final dose is $17 \mathrm{gr}$ of bread. The time interval between each dose is $30 \mathrm{~min}$.

\section{Results}

All 27 children presented different levels of IgE to wheat. 13 of them reacted during oral food challenge with clinical symptoms: 7 asthma attack, 10 urtikaria, 7 abdominal symptoms. We observed higher IgE levels to wheat in children who presented clinical symptoms during food challenge and additionally most of them showed to be positive to IgE antibodies to $\omega-5$ gliadin.

${ }^{1}$ Astrid Lindgren Hospital, Karolinska Institute, Allergi, astma, Stockholm, Sweden

Full list of author information is available at the end of the article
We also observed that higher levels of IgE to wheat were correlated to reactions to lower doses of wheat.

Our findings suggest that IgE antibodies to wheat alone cannot predict the outcome of food challenge and additional markers, such as $\omega-5$ gliadin should be identified in order to improve the diagnostic workup for wheat allergy.

\section{Author details}

${ }^{1}$ Astrid Lindgren Hospital, Karolinska Institute, Allergi, astma, Stockholm, Sweden. ${ }^{2}$ Karolinska Institutet, Department of Woman and Child Health and Centre for Allergy Research, Stockholm, Sweden. ${ }^{3}$ Karolinska Institutet and Sachs' Children's Hospital, Department of Clinical Science and Education Södesjukhuset, Stockholm, Sweden. ${ }^{4}$ Sahlgrenska Academy of Göteborg University, Department of Pediatrics, Göteborg, Sweden.

Published: 12 August 2011

doi:10.1186/2045-7022-1-S1-P64

Cite this article as: Nilsson et al.: Peadiatric wheat challenge studypreliminary results. Clinical and Translational Allergy 2011 1(Suppl 1):P64.
Submit your next manuscript to BioMed Central and take full advantage of:

- Convenient online submission

- Thorough peer review

- No space constraints or color figure charges

- Immediate publication on acceptance

- Inclusion in PubMed, CAS, Scopus and Google Scholar

- Research which is freely available for redistribution

Submit your manuscript at www.biomedcentral.com/submit
() Biomed Central
C Biomed Central

(c) 2011 Nilsson et al; licensee BioMed Central Ltd. This is an open access article distributed under the terms of the Creative Commons Attribution License (http://creativecommons.org/licenses/by/2.0), which permits unrestricted use, distribution, and reproduction in any medium, provided the original work is properly cited. 